\title{
Intention as a Mediator between Attitudes, Subjective Norms, and Cyberloafing among Preservice Teachers of English
}

\author{
Ceyhun Karabıyı* \\ Department of Foreign Language Teaching, Ufuk University, Ankara, Turkey, ORCID: \\ https://orcid.org/0000-0003-1408-931X \\ Meltem Huri Baturay \\ Center for Teaching and Learning, Atılim University, Ankara, Turkey; ORCID: \\ https://orcid.org/0000-0003-2402-6275
}

\section{Muzaffer Özdemir}

Department of Computer Education and Instructional Technology, Çanakkale Onsekiz Mart University, Çanakkale, Turkey; ORCID: https://orcid.org/0000-0002-5490-238X

Article history

Received:

16.07.2020

Received in revised form: 14.11.2020

Accepted:

18.11.2020

Key words:

Cyberloafing, attitude, subjective norms, behavioral intention, mediator
Learning and teaching is fostered to a great deal by technology. Cell phones and internet can be utilized as effective tools in providing extended and diversified learning opportunities as well as promoters of learning and teaching. However, early internet-enabled cell phones or more recent smartphones have also become easily accessible avenues of distraction and escape. This study explored if and how intention to cyberloaf acts as a mediator in the relationship between attitudes, subjective norms, and cyberloafing with a focus on descriptive and prescriptive norms with respect to instructors and classmates separately. The research was undertaken at a foundation university in Ankara, Turkey with 214 preservice English teachers. The sample consisted of $152(71.03 \%)$ females and $62(28.97 \%)$ males. Cyberloafing scale developed by Kalaycı (2010), adapted versions of Askew et al.'s (2014) attitudes towards cyberloafing scale, subjective descriptive norms scale, cyberloafing intentions scale, and Blanchard and Henle's (2008) norms scale were used as data collection instruments. Mediation analyses were performed using SPSS 22 with the utilization of SPSS macro, PROCESS v 3.4 (Hayes, 2017). The results of the regression analyses indicated that subjective norms and attitudes significantly predicted cyberloafing; and intentions to cyberloaf was found to be a significant but partial mediator between the variables. The results have significant implications both for academic research on cyberloafing and for educational practices.

\section{Introduction}

Uses of technology are manifold and can be resorted to by individuals to engage in actions that move them away from their contextual objectives, which are termed as cyberdeviance behaviors. These range from relatively harmless acts like cyberloafing to more

\footnotetext{
*Correspondency: : ceyhun.karabiyik@ufuk.edu.tr
} 
harmful ones like hacking, cyber piracy, theft, and cyber-aggression (Charlier, Giumetti, Reeves, \& Greco, 2017). In this context, use of the internet for non-class related purposes during class hours in physical or the virtual settings is a cause of concern (Akbulut, Dursun, Dönmez, \& Şahin, 2016). Termed as either cyberslacking (Greengard, 2000) or cyberloafing (Polito, 1997), it can be undertaken by various technological means like computers, personal computers, tablets, cell phones, and smartphones depending on the educational setting and availability. Nowadays, most students own such devices and bring them into their classroom settings. In fact, the ownership and usage of smartphones in classes was found to increase the likelihood of engaging with problematic Information and Communication Technology (ICT) behaviors like cyberloafing (Dursun, Dönmez, \& Akbulut, 2018; Rodríguez-Gómez, Castro, $\&$ Meneses, 2018). According to research studies, such behaviors center around online socialization via social networks, news follow-up, and personal affairs like chatting and send/receiving e-mails (Arabac1, 2017; Bağrıçık-Yılmaz, 2017; Baturay \& Toker, 2015; Koay, 2018; Seçkin \& Kerse, 2017; Varol \& Yıldırım, 2017).

Students engage in cyberloafing behaviors for many reasons. In a study carried out by Bağriaçık-Yılmaz (2017) with graduate students, some of these were unearthed. The study results determined curiosity, interest, distractibility, problems with focusing, rationalization, boredom, dislike of subject matter, tiredness, need for relaxation, notices, internet access as some of the main reasons that students are engaged with such behaviors. In other studies, social network use (Dursun et al., 2018), stress and social support (Gökçearslan, Uluyol, \& Şahin, 2018) were also identified as reasons for students' cyberloafing behaviors.

As it is the case for many types of deviant behaviors cyberloafing also directly or indirectly leads to some problems in classrooms. According to Sarıtepeci (2019), these endeavors adversely affect the efficiency and productivity of learning and teaching. In this regard, it was determined that cyberloafing distracted students and decreased their participation (Brubaker, 2006), resulted in less engagement and academic dishonesty (Skolnik \& Puzo, 2008), and even less happiness (Haidari, 2018). Not surprisingly, it was also determined to result in lower academic outcomes (Dursun et al., 2018; Ravizza, Hambrick, \& Fenn, 2014).

Studies contextualized in educational settings have shown that voluntary behaviors like cyberloafing (Lim, 2002) have certain antecedents. Among these, behavioral intention to carry out such acts is one of the key variables. As defined by Fishbein and Ajzen (2011) behavioral intentions are a sign of a person's readiness to execute a behavior. Indeed, a positive association between behavioral intentions and actual and perceived technology use have been reported by studies undertaken in the educational contexts (Schepers \& Wetzels, 2007; Scherer, Siddiq, \& Tondeur, 2019; Szajna, 1996). Moreover, intention to cyberloaf was also determined to be a positive correlate of cyberloafing behavior (Askew, Buckner, Taing, Ilie, Bauer, \& Coovert, 2014; Askew, Ilie, Bauer, Simonet, Buckner, \& Robertson, 2019).

Subjective norms predict behavioral intention, which is a significant promoter of behavior (Ajzen, 1991). Essentially, subjective norms are an individual's beliefs about undertaking a behavior or not and are classified under two broad terms that are prescriptive and descriptive. The former refers to what referent others say is acceptable behavior (Askew et al., 2014; Blanchard \& Henle, 2008; Soh, Koay, \& Lim, 2018); whereas the latter represents what referent others do (Askew et al., 2014; Cialdini, Reno, \& Kallgren, 1990; Park \& Smith, 2007; Soh et al., 2018). In educational settings, as far as cyberloafing is considered, prescriptive norms can be defined as the extent to which classmates or instructors would approve of the student's cyberloafing, whereas descriptive norms can be described as the 
extent to which students and instructors cyberloaf themselves. A second distinction in subjective norm evident in literature is based on referent types (Lapinski \& Rimal, 2005). In this regard, instructors and classmates are the key referents. Instructors have the authority to punish students formally or informally for undertaking deviant behaviors. Besides, they also act as role models for certain behavioral adoptions and adaptations. In a similar vein, the influence of classmates on students is evident in all education systems (Mantovani \& Martini, 2008). A review of the related line of literature shows that a positive relationship between norms and behavioral intentions have been uncovered in educational contexts (Gerow, Galluch, \& Thatcher, 2010; Galluch \& Thatcher, 2011; Taneja, Fiore, \& Fischer, 2015; Schepers \& Wetzels, 2007; Soh et al., 2018). Likewise, a positive relationship between norms and technology use was also reported in some studies (Schepers \& Wetzels, 2007; Teo \& van Schaik, 2012). In the same line, research also supports the positive link between cyberloafing and descriptive and prescriptive norms (Askew et al., 2014; Askew et al., 2019) as well as the link between cyberloafing and descriptive and prescriptive norms with respect to both superiors and co-ordinates (Askew et al., 2019).

Attitudes toward a behavior is gained when an individual establishes a belief about the consequences of performing that behavior automatically and simultaneously (Fishbein \& Ajzen, 1975). Tao (2008) defines attitude as an individual's evaluation of performing the behavior and Pathirana and Azam (2017) characterize it as the sum of beliefs attributed to a behavior. The positive relationship between attitudes towards a behavior and behavioral intentions (Kırmız1, 2014; Scherer et al., 2019; Soh, et al., 2018; Schepers \& Wetzels, 2007; Taneja, et al., 2015; Teo, 2009; Teo, Lee, Chai, \& Wong, 2009; Teo \& Militunovic, 2015) as well as the positive correlation between attitudes and technology use (Schepers \& Wetzels, 2007; Scherer et al., 2019; Teo \& van Schaik, 2012) are well-documented across a number of studies in educational settings. The positive correlation between attitudes towards cyberloafing and cyberloafing intentions as well as the positive link between cyberloafing attitudes and actual cyberloafing behaviors were also revealed by Askew et al. (2014).

To contribute to the line of research, the current study focuses on the relationship between attitudes, norms, and cyberloafing as a type of deviant technology use in the higher education setting, seeking to uncover the influence of behavioral intentions within this relationship. Distinct from previous studies in the field of education, this study will incorporate descriptive and prescriptive norms with respect to instructors and classmates separately. Therefore, four distinct regression analyses were used to test the relevant hypotheses. The first set of hypotheses included attitudes towards cyberloafing, descriptive norms regard instructors, intention to cyberloaf, and cyberloafing as variables. In the analysis the causal agents were attitudes towards cyberloafing and descriptive norms regards instructors, the mediator variable was intention to cyberloaf, and the outcome variable was cyberloafing. The related set of hypotheses that were tested are as follows:

(1) Attitudes towards cyberloafing and descriptive norms for instructors will predict cyberloafing.

(2) Attitudes towards cyberloafing and descriptive norms for instructors will predict intentions to cyberloaf.

(3) Intentions to cyberloaf will predict cyberloafing in the presence of attitudes towards cyberloafing and descriptive norms regard instructors as predictor.

(4) The power of attitudes towards cyberloafing and descriptive norms regard instructors in predicting cyberloafing will be reduced when intentions to cyberloaf is also included as predictor. 
The second regression analyses included attitudes towards cyberloafing and prescriptive norms regard instructors as causal agents, intention to cyberloaf as the mediator, and cyberloafing as the outcome variable. The concerned sets of hypotheses that were tested are as follows:

(5) Attitudes towards cyberloafing and prescriptive norms regard instructors will predict cyberloafing.

(6) Attitudes towards cyberloafing and prescriptive norms regard instructors will predict intentions to cyberloaf.

(7) Intentions to cyberloaf will predict cyberloafing in the presence of attitudes towards cyberloafing and prescriptive norms regard instructors as predictor.

(8) The power of attitudes towards cyberloafing and prescriptive norms regard instructors in predicting cyberloafing will be reduced when intentions to cyberloaf is also included as predictor.

In the third set of regression analyses, causal agents were attitudes towards cyberloafing and descriptive norms regard classmates. Similar to the previous sets of hypotheses, intention to cyberloaf was the mediator variable and cyberloafing was the outcome variable. The relevant sets of hypotheses that were tested are as follows:

(9) Attitudes towards cyberloafing and descriptive norms regard classmates will predict cyberloafing.

(10) Attitudes towards cyberloafing and descriptive norms regard classmates will predict intentions to cyberloaf.

(11) Intentions to cyberloaf will predict cyberloafing in the presence of attitudes towards cyberloafing and descriptive norms regard classmates as predictor.

(12) The power of attitudes towards cyberloafing and descriptive norms regard classmates in predicting cyberloafing will be reduced when intentions to cyberloaf is also included as predictor.

In the fourth and last set of regression analyses, attitudes towards cyberloafing and prescriptive norms regard classmates were the casual agents. Again, the variable named intention to cyberloaf was the mediator variable and the outcome variable was cyberloafing. The pertinent sets of hypotheses that were tested are as follows:

(13) Attitudes towards cyberloafing and prescriptive norms regard classmates will predict cyberloafing.

(14) Attitudes towards cyberloafing and prescriptive norms regard classmates will predict intentions to cyberloaf.

(15) Intentions to cyberloaf will predict cyberloafing in the presence of attitudes towards cyberloafing and prescriptive norms regard classmates as predictor.

(16) The power of attitudes towards cyberloafing and prescriptive norms regard classmates in predicting cyberloafing will be reduced when intentions to cyberloaf is also included as predictor. 


\section{Method}

\subsection{Participants and Setting}

The study consisted of a total of 214 students that were enrolled in the English language teaching program at Ufuk University, Ankara, Turkey. The department offers a four-year English language teaching degree. The participants were enrolled in the program with respect to the centrally administered university entrance exam and had homogeneous entry levels. Of the 214 participants, 152 (71.03\%) were female and 62 (28.97\%) were male and the average age of the participants was 20.18 .

\subsection{Measures}

The paper and pencil survey instrument distributed included demographic questions (i.e. gender and age) as well as the following measures:

\subsubsection{Attitudes towards cyberloafing}

It was measured by a four-item measure adapted from Askew et al. (2014) to the educational settings by the researchers asking students to determine their view on cyberloafing in class for personal reasons. Each item was scored on a seven-point Likert scale ranging between worthless (1) to valuable (7), unenjoyable (1) to unenjoyable (7), harmful (1) to beneficial (7), and bad (1) to (good). The overall reliability coefficient for the scale was 81 .

\subsubsection{Cyberloafing}

It was measured using Kalaycı's (2010) cyberloafing scale, which is an adapted version of Blanchard and Henle's (2008) scale. It includes thirteen questions related to social network use (e.g. visiting social networking sites), news follow-up (e.g. visiting news sites), and personal use (e.g. doing online shopping) and is scored on a five-point Likert scale ranging between never (1) to always (5). The reliability coefficient for the measure was 87 .

\subsubsection{Descriptive norms}

Askew et al.'s (2014) subjective descriptive norms scale was adapted to the educational setting by changing the referents as instructor and classmates and was used to measure the extent to which students thought that their instructors and classmates engaged in non-class related online activities during lectures. The scale includes three questions (e.g. How often do your instructors/classmates check non-class related e-mail?) for each referent category and was scored on a six-point scale ranging between strongly never (1) to constantly (6). The reliability coefficients for the classmate and instructor categories were .71 and .88, respectively.

\subsubsection{Intentions to cyberloaf}

Six items Cyberloafing Intentions Scale of Askew et al. (2014) was adapted to the educational setting and used for the research. It consists of items asking participants to evaluate their cyberloafing behaviors (e.g. shop online, browsing). It is scored on a five-point Likert scale ranging from strongly disagree (1) to strongly agree (5). The reliability of the scale was determined to be .78 . 


\subsubsection{Prescriptive norms}

Blanchard and Henle's (2008) norms scale was adapted to the educational setting and used to quantify participants' subjective prescriptive norms. Participants were asked to determine the extent to which their instructors (e.g. my instructors will approve of me visiting social networking sites) and classmates (e.g. my classmates will approve of me visiting nonclass related websites) would approve of them using internet for non-class purposes during the lectures. The scale included the same three questions for each referent and was scored on a five-point Likert scale ranging between strongly disagree (1) to strongly agree (5). The reliability coefficients for the classmate and instructor categories were .83 and .91, respectively.

\subsection{Data Collection}

First, ethical approval was granted from the Ufuk University Social and Human Sciences Scientific Research and Publication Ethics Committee. After that, students were invited to complete an anonymous paper and pencil survey that asked questions on their cyberloafing, intentions to cyberloaf, attitudes towards cyberloafing, descriptive norms regard classmates and instructors concerning cyberloafing in class, and prescriptive norms regard classmates and instructors for cyberloafing in class. Participation was voluntary and participants were guaranteed of compliance with confidentiality. The surveys were distributed during class hours and participants were kindly asked to complete and return them in a week. After the collection of the questionnaires, the data was entered to Statistical Package for the Social Sciences (SPSS) version 22 for analysis.

\subsection{Data Analysis}

At first, data was obtained from 217 participants and checked for missing values. Upon determining that there were no missing data, multivariate outliers were assessed using the Mahalanobis distance measure and accordingly 3 entries were deleted. After that the normality of the data was checked and no violation of normality was found. As a result, the final data set was composed of 214 entries. After that, descriptive statistics, internal consistencies of the scales (Cronbach's $\alpha$ ), and inter-correlations (Pearson's correlation coefficient) between variables were computed.

Next, four distinct mediation analyses were performed using SPSS 22 that included the testing of the hypotheses using SPSS macro, PROCESS v 3.4 (Hayes, 2017) using model 4. According to Frazier, Tix, and Barron (2004) mediation analyses can be conducted with either multiple regression analyses or structural equation modelling (SEM) as the logic behind both analyses are the same. Due to the limitations of SEM when estimating mediation models (Hayes, Montoya, \& Rockwood, 2017), the PROCESS approach to mediation analysis, which is considered as the norm for performing mediation analyses in most social sciences research (Sarstedt, Hair Jr., Nitzl, Ringle, \& Howard, 2020), was adopted. The PROCESS approach blends the normal theory approach (Sobel, 1982) to enable the estimation of indirect effects, the bootstrap approach (Preacher \& Hayes, 2004) to obtain confidence intervals, and the traditional approach put forth by Baron and Kenny (1986), which posits that in order to identify a variable as a mediator, the independent variable must predict the dependent variable, the independent variable must predict the mediator variable, and the predictive power of the independent variable on the dependent variable must either be zeroed or reduced when entered into the regression equation with the mediator variable. In cases where the effect is zeroed, this is called perfect mediation; on the other hand, when the effect of the 
independent variable on the dependent variable decreases but is higher than zero then this is called partial mediation (Preacher \& Hayes, 2004).

\section{Results}

To analyze possible interactions between variables Pearson's correlation coefficient test was conducted. Bivariate correlations between variables used in the study are displayed in Table 1.

Table 1. Descriptive statistics, correlations, and reliabilities

\begin{tabular}{llllllllll}
\hline Variable & $\mathbf{M}$ & SD & $\mathbf{1}$ & $\mathbf{2}$ & $\mathbf{3}$ & $\mathbf{4}$ & $\mathbf{5}$ & $\mathbf{6}$ & $\mathbf{7}$ \\
\hline 1. Cyberloafing & 2.44 & .84 & 1 & & & & & & \\
2. Intentions & 3.03 & .83 & $.44^{* *}$ & 1 & & & & & \\
3. Attitudes & 4.73 & 2.13 & $.39^{* *}$ & $.37^{* *}$ & 1 & & & & \\
4. Des. Ns. INs. & 4.31 & 1.02 & $.56^{* *}$ & $.38^{* *}$ & $.30^{* *}$ & 1 & & & \\
5. Des. Ns. CMs. & 2.29 & 1.42 & $.32^{* *}$ & $.38^{* *}$ & .02 & .12 & 1 & & \\
6. Pres. Ns. Is. & 3.10 & .98 & $.55^{* *}$ & $.38^{* *}$ & $.27^{* *}$ & $.66^{* *}$ & $.17^{*}$ & 1 & \\
7. Pres. Ns. CMs. & 2.26 & 1.28 & $.28^{* *}$ & $.35^{* *}$ & $.19^{* *}$ & $.31^{* *}$ & $.31^{* *}$ & $.37^{* *}$ & 1 \\
\hline
\end{tabular}

$\mathrm{N}=214, * \mathrm{p}<.05, * * \mathrm{p}<.01$

Bivariate correlations presented in Table 1 show that cyberloafing was positively and significantly correlated with intentions to cyberloaf, attitudes towards cyberloafing, descriptive norms regard instructors (Des. Ns. Is.) and classmates (Des. Ns. CMs.), and prescriptive norms regard instructors (Pres. Ns. Is.) and classmates (Pres. Ns. CMs.). Significant positive relationships were also observed between intentions to cyberloaf and attitudes towards cyberloafing, descriptive norms regard instructors and classmates, and prescriptive norms regard instructors and classmates. Moreover, attitudes towards cyberloafing had significant and positive relationships with descriptive norms regard instructors, prescriptive norms regard instructors and prescriptive norms regard classmates. Besides, descriptive norms regard instructors and classmates were positively related with both prescriptive norms regard instructors and classmates. Lastly, there was a significant positive relationship between prescriptive norms regard instructors and prescriptive norms regard classmates.

Next, the first set of regression analyses were carried out to test the first mediation analysis that involved the testing of hypotheses $\mathrm{H} 1-\mathrm{H} 4$. In these analyses, cyberloafing was the outcome variable, attitudes towards cyberloafing and descriptive norms regard instructors were predictors, and intentions to cyberloaf was the mediator variable. The results of the regression analyses are presented in Table 2 .

Table 2. Regression analyses to test the mediation of intention in the relationship between attitudes, descriptive norms regard instructors and cyberloafing

\begin{tabular}{llllll}
\hline Criterion/predictor & $\mathbf{b}$ & $\mathbf{S E}$ & $\mathbf{t}$ & $\mathbf{9 5 \%} \mathbf{C I}$ & $\mathbf{R}^{\mathbf{2}}$ \\
\hline H1: Cyberloafing & & & & & $.37^{* *}$ \\
Attitudes towards cyberloafing & .30 & .07 & $4.13^{* *}$ & $.09-.24$ & \\
Des. norms regard instructors & 1.26 & .15 & $8.56^{* *}$ & $.19-.49$ &
\end{tabular}

$\mathrm{H} 2$ : Intention 


\begin{tabular}{llllll}
\hline Criterion/predictor & $\mathbf{b}$ & $\mathbf{S E}$ & $\mathbf{t}$ & $\mathbf{9 5 \%} \mathbf{C I}$ & $\mathbf{R}^{\mathbf{2}}$ \\
\hline Attitudes towards cyberloafing & .16 & .04 & $4.33^{* *}$ & $.09-.24$ \\
Des. norms regard instructors & .34 & .08 & $4.53^{* *}$ & $.19-.49$ & $.41^{* *}$ \\
H3-4: Cyberloafing & & & & & \\
Intention to cyberloaf & .48 & .13 & $3.66^{* *}$ & $.22-.74$ & $.08-.37$ \\
Attitudes towards cyberloafing & .23 & .07 & $3.03^{* *}$ & $.80-1.40$ \\
Des. norms regard instructors & 1.10 & .15 & $7.32^{* *}$ & .00 \\
\hline
\end{tabular}

$* \mathrm{p}<.05, * * \mathrm{p}<.01$

As it can be observed from the Table 2, in Step 1 of the mediation analysis, attitudes towards cyberloafing and descriptive norms regard instructors significantly predicted cyberloafing, $\left(\mathrm{b}_{\mathrm{ATC}}=.30, \mathrm{t}(211)=4.13, \mathrm{p}<.001 ; \mathrm{b}_{\mathrm{DNI}}=1.26, \mathrm{t}(211)=8.56, \mathrm{p}<.001\right)$, while ignoring the mediator. Step 2 showed that attitudes towards cyberloafing and descriptive norms regard instructors significantly predicted intentions to cyberloaf $\left(\mathrm{b}_{\mathrm{ATC}}=.16, \mathrm{t}(211)=4.33, \mathrm{p}<.001\right.$; $\left.\mathrm{b}_{\mathrm{DNI}}=.34, \mathrm{t}(211)=4.53, \mathrm{p}<.001\right)$. Step 3 of the mediation process showed that the mediator (intention to cyberloaf), controlling for attitudes towards cyberloafing and descriptive norms regard instructors was significant $\left(b_{\mathrm{INT}}=.48, \mathrm{t}(211)=3.66, \mathrm{p}<.001\right)$. Step 4 of the analyses revealed that, controlling for the mediator (intention to cyberloaf), attitudes towards cyberloafing and descriptive norms regard instructors were significant predictors of cyberloafing $\left(\mathrm{b}_{\mathrm{ATC}}=.23, \mathrm{t}(211)=3.03, \mathrm{p}<.001 ; \mathrm{b}_{\mathrm{DNI}}=1.10, \mathrm{t}(211)=7.32, \mathrm{p}<.001\right)$. Significance of the indirect effect was analyzed using bootstrapping procedures that involved 5000 samples and 95\% confidence interval (Preacher \& Hayes, 2008). The indirect effect (.08) of attitudes towards cyberloafing and descriptive norms regard instructors through intention to cyberloaf on cyberloafing was significant ( $\mathrm{SE}=.03,95 \% \mathrm{CI}[.03-.14]$ ). In short, attitudes towards cyberloafing and descriptive norms regard instructors were associated with cyberloafing that was 8 points higher as mediated by intentions to cyberloaf and as the effects of the independent variables on the dependent variable were not zeroed but only reduced when entered into the regression equation with the mediator variable it is valid to state that the nature of the mediation was partial (Preacher \& Hayes, 2004).

Next, the second set of regression analyses were undertaken to test hypotheses H5-H8. In these analyses, cyberloafing was the outcome variable, attitudes towards cyberloafing and prescriptive norms regard instructors were predictors, and intentions to cyberloaf was the mediator variable. The results of the regression analyses are shown in Table 3.

Table 3. Regression analyses to test the mediation of intention in the relationship between attitudes, prescriptive norms regard instructors and cyberloafing

\begin{tabular}{|c|c|c|c|c|c|}
\hline Criterion/predictor & $\mathbf{b}$ & SE & $\mathbf{T}$ & $95 \% \mathrm{CI}$ & $\mathbf{R}^{2}$ \\
\hline H5: Cyberloafing & & & & & $.36^{* *}$ \\
\hline Attitudes towards cyberloafing & .33 & .07 & $4.53 * *$ & $.19-.47$ & \\
\hline Pres. norms regard instructors & 1.37 & .16 & $8.42 * *$ & $1.05-1.68$ & \\
\hline H6: Intention & & & & & $.22 * *$ \\
\hline Attitudes towards cyberloafing & .17 & .04 & $4.52 * *$ & $.09-.24$ & \\
\hline Pres. norms regard instructors & .39 & .08 & $4.84 * *$ & $.23-.55$ & \\
\hline H7-8: Cyberloafing & & & & & $.40 * *$ \\
\hline Intention to cyberloaf & .47 & .13 & $3.52 * *$ & $.21-.73$ & \\
\hline Attitudes towards cyberloafing & .25 & .07 & $3.40 * *$ & $.11-.40$ & \\
\hline Pres. norms regard instructors & 1.18 & .17 & $7.08 * *$ & $.85-1.51$ & \\
\hline
\end{tabular}

$* \mathrm{p}<.05, * * \mathrm{p}<.01$

As it can be observed from the Table 3, in Step 1 of the mediation analyses, attitudes to cyberloaf and prescriptive norms regard instructors significantly predicted cyberloafing, 
$\left(\mathrm{b}_{\mathrm{ATC}}=.33, \mathrm{t}(211)=4.53, \mathrm{p}<.001 ; \mathrm{b}_{\mathrm{PNI}}=1.37, \mathrm{t}(211)=8.42, \mathrm{p}<.001\right)$, while ignoring the mediator. Step 2 showed that attitudes to cyberloaf and prescriptive norms regard instructors significantly predicted intentions to cyberloaf $\left(\mathrm{b}_{\mathrm{ATC}}=.17, \mathrm{t}(211)=4.52, \mathrm{p}<.001 ; \mathrm{b}_{\mathrm{PNI}}=.39\right.$, $\mathrm{t}(211)=4.84, \mathrm{p}<.001)$. Step 3 of the mediation process showed that the mediator (intention to cyberloaf), controlling for attitudes towards cyberloafing and prescriptive norms regard instructors was significant $\left(b_{\mathrm{INT}}=.47, \mathrm{t}(211)=3.52, \mathrm{p}<.001\right)$. Step 4 of the analyses revealed that, controlling for the mediator (intention to cyberloaf), attitudes towards cyberloafing and prescriptive norms regard instructors were significant predictors of cyberloafing $\left(\mathrm{b}_{\mathrm{ATC}}=.25\right.$, $\left.\mathrm{t}(211)=3.40, \mathrm{p}<.001 ; \mathrm{b}_{\mathrm{PNI}}=1.18, \mathrm{t}(211)=7.08, \mathrm{p}<.001\right)$. Significance of the indirect effect was analyzed using bootstrapping procedures that involved 5000 samples and 95\% confidence interval (Preacher \& Hayes, 2008). The indirect effect (.08) of attitudes towards cyberloafing and prescriptive norms regard instructors through intention to cyberloaf on cyberloafing was significant ( $\mathrm{SE}=.03,95 \%$ CI [.03-.14]). To sum up, attitudes towards cyberloafing and prescriptive norms regard instructors were associated with cyberloafing that was 8 points higher as mediated by intentions to cyberloaf and since the predictive utility of the independent variables on the dependent variable were not zeroed but only reduced when entered into the regression equation with the mediator variable it is valid to state that the nature of the mediation was partial (Preacher \& Hayes, 2004).

A third set of regression analyses were undertaken to test hypotheses H9-H12. In these analyses, cyberloafing was the outcome variable, attitudes towards cyberloafing and descriptive norms regard classmates were predictors, and intentions to cyberloaf was the mediator variable. The results of the regression analyses are indicated in Table 4.

Table 4. Regression analyses to test the mediation of intention in the relationship between attitudes, descriptive norms regard classmates and cyberloafing

\begin{tabular}{|c|c|c|c|c|c|}
\hline Criterion/predictor & $\mathbf{b}$ & $\mathbf{S E}$ & $\mathbf{T}$ & $95 \% \mathrm{CI}$ & $\mathbf{R}^{2}$ \\
\hline H9: Cyberloafing & & & & & $.25^{* *}$ \\
\hline Attitudes towards cyberloafing & .49 & .08 & $6.35 * *$ & $.33-.64$ & \\
\hline Des. norms regard classmates & 1.12 & .21 & $5.23 * *$ & $.70-1.54$ & \\
\hline H10: Intention & & & & & $.27 * *$ \\
\hline Attitudes towards cyberloafing & .21 & .03 & $6.09 * *$ & $.14-.28$ & \\
\hline Des. norms regard classmates & .60 & .09 & $6.28 * *$ & $.41-.79$ & \\
\hline H11-12: Cyberloafing & & & & & $.29 * *$ \\
\hline Intention to cyberloaf & .57 & .15 & $3.78 * *$ & $.27-.86$ & \\
\hline Attitudes towards cyberloafing & .37 & .08 & $4.57 * *$ & $.21-.53$ & \\
\hline Des. norms regard classmates & .78 & .23 & $3.45 * *$ & $.33-1.22$ & \\
\hline
\end{tabular}

$* \mathrm{p}<.05, * * \mathrm{p}<.01$

As it is reported in Table 4, in Step 1 of the mediation analyses, attitudes towards cyberloafing and descriptive norms regard classmates significantly predicted cyberloafing, $\left(\mathrm{b}_{\mathrm{ATC}}=.49, \mathrm{t}(211)=6.35, \mathrm{p}<.001 ; \mathrm{b}_{\mathrm{DNCM}}=1.12, \mathrm{t}(211)=5.23, \mathrm{p}<.001\right)$, while ignoring the mediator. Step 2 showed that attitudes towards cyberloafing and descriptive norms regard classmates significantly predicted intentions to cyberloaf $\left(\mathrm{b}_{\mathrm{ATC}}=.21, \mathrm{t}(211)=6.09, \mathrm{p}<.001\right.$; $\left.\mathrm{b}_{\mathrm{DNCM}}=.60, \mathrm{t}(211)=6.28, \mathrm{p}<.001\right)$. Step 3 of the mediation process showed that the mediator (intention to cyberloaf), controlling for attitudes towards cyberloafing and descriptive norms regard classmates was significant $\left(b_{\mathrm{INT}}=.57, \mathrm{t}(211)=3.78, \mathrm{p}<.001\right)$. Step 4 of the analyses revealed that, controlling for the mediator (intention to cyberloaf), attitudes towards cyberloafing and descriptive norms regard classmates were significant predictors of cyberloafing $\left(\mathrm{b}_{\mathrm{ATC}}=.37, \mathrm{t}(211)=4.57, \mathrm{p}<.001 ; \mathrm{b}_{\mathrm{DNCM}}=.78, \mathrm{t}(211)=3.45, \mathrm{p}<.001\right)$. Significance of the indirect effect was analyzed using bootstrapping procedures that involved 
5000 samples and 95\% confidence interval (Preacher \& Hayes, 2008). The indirect effect (.12) of attitudes towards cyberloafing and descriptive norms regard classmates through intention to cyberloaf on cyberloafing was significant ( $\mathrm{SE}=.04,95 \%$ CI [.05-.20]). In brief, attitudes towards cyberloafing and descriptive norms regard classmates were associated with cyberloafing that was 12 points higher as mediated by intentions to cyberloaf and as the predictive power of the independent variables on the dependent variable were not zeroed but only reduced when entered into the regression equation with the mediator variable it is valid to state that the nature of the mediation was partial (Preacher \& Hayes, 2004).

The last set of regression analyses were undertaken to test hypotheses H13-H16. In these analyses, cyberloafing was the outcome variable, attitudes towards cyberloafing and prescriptive norms regard classmates were predictors, and intentions to cyberloaf was the mediator variable. The results of the regression analyses are shown in Table 5.

Table 5. Regression analyses to test the mediation of intention in the relationship between attitudes, prescriptive norms regard classmates and cyberloafing

\begin{tabular}{|c|c|c|c|c|c|}
\hline Criterion/predictor & $\mathbf{b}$ & SE & $\mathbf{T}$ & $95 \% \mathrm{CI}$ & $\mathbf{R}^{2}$ \\
\hline H13: Cyberloafing & & & & & $.20 * *$ \\
\hline Attitudes towards cyberloafing & .44 & .08 & $5.49 * *$ & $.28-.60$ & \\
\hline Pres. norms regard classmates & .81 & .23 & $3.47 * *$ & $.35-1.28$ & \\
\hline H14: Intention & & & & & $.21 * *$ \\
\hline Attitudes towards cyberloafing & .18 & .04 & $5.03 * *$ & $.11-.25$ & \\
\hline Pres. norms regard classmates & .49 & .11 & $4.62 * *$ & $.28-.69$ & \\
\hline H15-16: Cyberloafing & & & & & $.27 * *$ \\
\hline Intention to cyberloaf & .68 & .15 & $4.63 * *$ & $.39-.97$ & \\
\hline Attitudes towards cyberloafing & .32 & .08 & $3.92 * *$ & $.16-.48$ & \\
\hline Pres. norms regard classmates & .48 & .24 & $2.06 * *$ & $.02-.95$ & \\
\hline
\end{tabular}

$* \mathrm{p}<.05, * * \mathrm{p}<.01$

As it is reported in Table 5, in Step 1 of the mediation analyses, attitudes to cyberloaf and prescriptive norms regard classmates significantly predicted cyberloafing, $\left(\mathrm{b}_{\mathrm{ATC}}=.44, \mathrm{t}(211)=\right.$ $\left.5.49, \mathrm{p}<.001 ; \mathrm{b}_{\mathrm{PNCM}}=.81, \mathrm{t}(211)=3.47, \mathrm{p}<.001\right)$, while ignoring the mediator. Step 2 showed that attitudes to cyberloaf and prescriptive norms regard classmates significantly predicted intentions to cyberloaf $\left(\mathrm{b}_{\mathrm{ATC}}=.18, \mathrm{t}(211)=5.03, \mathrm{p}<.001 ; \mathrm{b}_{\mathrm{PNCM}}=.49, \mathrm{t}(211)=4.62, \mathrm{p}<.001\right)$. Step 3 of the mediation process showed that the mediator (intention to cyberloaf), controlling for attitudes towards cyberloafing and prescriptive norms regard classmates was significant $\left(b_{\text {INT }}=.68, t(211)=4.63, \mathrm{p}<.001\right)$. Step 4 of the analyses revealed that, controlling for the mediator (intention to cyberloaf), attitudes towards cyberloafing and prescriptive norms regard classmates were significant predictors of cyberloafing $\left(b_{\mathrm{ATC}}=.32, \mathrm{t}(211)=3.92, \mathrm{p}<\right.$ $\left..001 ; b_{\mathrm{PNCM}}=.48, \mathrm{t}(211)=2.06, \mathrm{p}<.001\right)$. Significance of the indirect effect was analyzed using bootstrapping procedures that involved 5000 samples and 95\% confidence interval (Preacher \& Hayes, 2008). The indirect effect (.12) of attitudes towards cyberloafing and prescriptive norms regard classmates through intention to cyberloaf on cyberloafing was significant ( $\mathrm{SE}=.04,95 \% \mathrm{CI}[.06-.20]$ ). In conclusion, attitudes towards cyberloafing and prescriptive norms regard classmates were associated with cyberloafing that was 12 points higher as mediated by intentions to cyberloaf; however, as the effects of the independent variables on the dependent variable were not zeroed but only reduced when entered into the regression equation with the mediator variable it is valid to state that the nature of the mediation was partial (Preacher \& Hayes, 2004). 


\section{Discussion}

The current study investigated the relationship of attitudes towards cyberloafing, subjective norms, and intention to cyberloaf with cyberloafing behavior. To that end four distinct mediation analyses were performed to account for four types of subjective norms that are plausible in classroom settings that are descriptive norms regard instructors, prescriptive norms regard instructors, descriptive norms regard classmates and prescriptive norms regard classmates. Askew et al. (2014), similarly, tested the Theory Planned Behavior (TBP) as a model of cyberloafing. Their results indicated that descriptive norms, attitudes, and the ability to hide cyberloafing (as a perceived behavioral control construct) were found to predict cyberloafing above and beyond other predictors. That is, their results support the validity of the main TPB model as a model of cyberloafing. Thus, to our knowledge, this study is the first to show the mediating effect of intentions on the positive relationships between attitudes towards cyberloafing, subjective norms, and cyberloafing behavior in an educational context. Besides, this is the first study focusing on cyberloafing backed up by the Theory of Reasoned Actioned (TRA) as a framework.

In the first two analyses, attitudes towards cyberloafing and subjective norms (descriptive and prescriptive) regard instructors predicted cyberloafing. Moreover, intentions to cyberloaf partially mediated the relationships between these variables. Similarly, in the last two analyses, attitudes towards cyberloafing and subjective norms (descriptive and prescriptive) regard classmates not only predicted cyberloafing, but this relationship was also partially mediated by intentions to cyberloaf. In short, attitudes towards cyberloafing and subjective norms (descriptive and prescriptive) regard instructors and classmates concerning cyberloafing are not direct determinants of cyberloafing behavior but operate through an increase in intentions to cyberloaf. This result is consistent with behavioral theories like the TRA (Fishbein \& Ajzen, 1975; Ajzen \& Fishbein, 1980) and the Theory of Planned Behavior (TPB, Ajzen, 1985; 1991), which posit intentions as the most immediate predictor of behavior and mediator between other variables and the behavior.

\section{Implications for practice}

Some studies suggest that cyberloafing could be allowed to some extent to give some time to fuel up energy and to relax (Lim \& Chen, 2012). On the other hand, in educational settings students have their break times that are allocated in their daily class schedules to rest and relax. Class-time is limited and should not be wasted with cyberloafing, neither by students nor by instructors. However, the wide-spread ownership and use of smart phones by students at universities during class hours poses a challenge in this regard. Apart from being mobile, they offer a wide range of applications that appeal and attract their users (Gökçearslan et al., 2018) so these can easily shift their attention away from the subject during class hours. For that reason, instructors should try to capitalize on this interest and involvement by integrating mobile games into their lectures. Apart from being popular and collaborative, they are also highly engaging for students as they offer strong narratives by means of text, audio, video, and animation (Pim, 2013).

Results indicated that classmates' cyberloafing and their approval of such behavior encouraged students' intention and actual cyberloafing behavior. Therefore, it is important to make some decisions and implement them regularly at the organizational level to prevent cyberloafing in-class. What is suggested is a kind of cultural change which should be spread in the organization at institutional level. The decision-makers at schools may restrict students' cyberloafing by putting some rules. However, it is suggested in the literature that although 
some decision-makers worry about the high level of cyberloafing (Stewart, 2000), some others hesitate to implement heavy-handed practices by banning all computer use or monitoring internet traffic (De Lara, Tacoronte, \& Ding, 2006). Supporting restriction of students' cyberloafing, Soh et al. (2018) suggest that in order to prevent cyberloafing in a classroom, students may be informed about class ethics and the negative ramifications of cyberloafing. Only if their attitudes towards cyberloafing are changed they may refrain from performing this behavior (Soh et al., 2018).

The findings of the current study also indicated that instructors' cyberloafing and their approval of it associates with students' cyberloafing. This demonstrates that instructors should be careful about not cyberloafing during lecture hours. Instructors can act more strictly in cases where cyberloafing on the part of students occur. They can stress that they do not approve students' cyberloafing during class time to detract this behavior. As a precaution, students' seating plan can be arranged in a way that will enable instructors to monitor students' smartphone or computer screens in classrooms and computer labs. Teacher initiated or collaborative classroom rule setting can also be useful in preventing student cyberloafing via different media in the classrooms or computer labs.

Moreover, if students are engaged with in-class activities their level of cyberloafing may decrease. It is suggested that with a well-planned lecture, students may be more active in class and due to their engagement, these students will most probably not have time to cyberloaf (Soh et al., 2018). It is often emphasized that to eradicate the problem of cyberloafing there is a need for classroom practices that catch students' attention and satisfaction. Varol and Y1ldirım (2018) exemplified these classroom practices as educational games, videos, and different teaching methods to keep students motivated to support their learning.

There is a need for active learning activities to eliminate cyberloafing behaviors of students. Instructional methods employed by instructors and their classroom management skills are criticized while justifying cyberloafing. The lack of motivation is a barrier to learning as mention by several researchers (Bidabadi, Isfahani, Rouhollahi, \& Khalili, 2016; Bassett, Cleveland, Acorn, Nix, \& Snyder, 2017; Yasmin, Naseem, \& Masso, 2019). Instructors' failure in catching students' attention and satisfy students seemed to correlate with frequent cyberloafing. In this context, flipping the classroom can assist instructors in transforming students' learning experiences into an active learning opportunity. That is, dealing with theoretical information outside the classroom prior to attending a lecture and doing interactive practices in classroom may increase students' active participation and decrease their cyberloafing. Furthermore, techno-centric precautions in Information and Communication Technology classes such as screen monitoring and/or control software, and regulations regarding cell-phone use could be alternative options to hamper cyberloafing (Dursun et al., 2018). Yılmaz, Yılmaz, Özturk, Sezer, and Karademir (2015) suggest that it is significant to train instructors on the ethical use of technology and raise awareness on the issues to prevent cyberloafing.

\section{Limitations and suggestions for further research}

One important limitation of the study was the limited sample size, which included only a single higher education institution, and a single department. Replications of this study with larger sample sizes, diverse higher education institutions and departments can solidify the conceptualization of cyberloafing in diverse educational settings. Moreover, assessing cyberloafing at primary and secondary levels of education could also enrich the cyberloafing 
literature. Moreover, this study concentrated in providing an explanation to mediating role of intentions in the relationship between attitudes, subjective norms and cyberloafing in an educational setting. Future studies could concentrate on other independent, dependent, mediator, or moderator constructs from the field to provide a deeper understanding of cyberloafing, its antecedents, and consequences.

\section{Conclusion}

Cyberloafing is one of the concepts has been investigated more than a decade in the literature. Earlier studies focused on the behavior of cyberloafing and their effects on the performance of employees at work settings. Lately, the issue has been studied in educational settings as well. Today, every other classroom either at higher education or at K12 are equipped with wireless internet and tablet computers. Students as well have their mobile phones in their hands which arise the potential problem of cyberloafing especially for the students with low self-control skills. It is emphasized that banning these technologies in the classrooms is not a good way of eradicating problem, on the contrary it is against the desired ICT integration into education. One of the best prevention methods of restricting cyberloafing is to provide students with an active learning experience which will make them engaged in the lectures and instructors acting as role models who do not cyberloaf during lecture time. Another way to eradicate the cyberloafing problem could be to train students and instructors on ethical uses of technology.

\section{Acknowledgement}

This study was conducted by the researchers who are the members of LET-IN (LanguagE Teaching INnovations Research \& Development Group)

\section{References}

Ajzen, I. (1985). From Intentions to Actions: A Theory of Planned Behavior. Action Control, (pp. 11-39) Berlin, Heidelberg: Springer Berlin Heidelberg. doi:10.1007/978-3-64269746-3_2

Ajzen, I. (1991). The theory of planned behavior. Organizational Behavior and Human Decision Processes, 50(2), 179-211. doi:10.1016/0749-5978(91)90020-T

Ajzen, I., \& Fishbein, M. (1980). Understanding attitudes and predicting social behavior. Englewood-Cliffs: Prentice-Hall.

Akbulut, Y., Dursun, O. O., Dönmez, O., \& Şahin, Y. L. (2016). In search of a measure to investigate cyberloafing in educational settings. Computers in Human Behavior, 55, 616-625.

Arabac1, I. B. (2017). Investigation Faculty of Education Students' Cyberloafing Behaviors in Terms of Various Variables. Turkish Online Journal of Educational TechnologyTOJET, 16(1), 72-82.

Askew, K., Buckner, J. E., Taing, M. U., Ilie, A., Bauer, J. A., \& Coovert, M. D. (2014). Explaining cyberloafing: The role of the theory of planned behavior. Computers in Human Behavior, 36, 510-519. doi: 10.1016/j.chb.2014.04.006

Askew, K., Ilie, A., Bauer, J. A., Simonet, D. V., Buckner, J. E., \& Robertson, T. A. (2019). Disentangling how coworkers and supervisors influence employee cyberloafing: what normative information are employees attending to? Journal of Leadership \& Organizational Studies, 26(4), 526-544.

Bağrıçık-Yılmaz, A. (2017). Lisansüstü öğrencilerinin siber aylaklık düzeylerinin çesitli değiskenler açısından incelenmesi: karma bir çalışma [Investigation of cyberloafing 
levels of graduate students in terms of various variables: a mixed method study]. Ahi Evran Univertsity Journal of Kırşehir Education Faculty (KEFAD), 18(2), 113-134.

Baron, R. M., \& Kenny, D. A. (1986). The moderator-mediator variable distinction in social psychological research: Conceptual, strategic, and statistical considerations. Journal of Personality and Social Psychology, 51(6), 1173-1182.

Bassett, J., Cleveland, A., Acorn, D., Nix, M., \& Snyder, T. (2017). Are they paying attention? Students' lack of motivation and attention potentially threaten the utility of course evaluations. Assessment \& Evaluation in Higher Education, 42(3), 431-442.

Baturay, M. H., \& Toker, S. (2015). An investigation of the impact of demographics on cyberloafing from an educational setting angle. Computers in Human Behavior, 50, 358-366.

Bidabadi, N. S., Isfahani, A. N., Rouhollahi, A., \& Khalili, R. (2016). Effective teaching methods in higher education: requirements and barriers. Journal of advances in medical education \& professionalism, 4(4), 170.

Blanchard, A. L., \& Henle, C. A. (2008). Correlates of different forms of cyberloafing: The role of norms and external locus of control. Computers in Human Behavior, 24, 10671084.

Brubaker, A. T. (2006). Faculty perceptions of the impact of student laptop use in a wireless internet environment on the classroom learning environment and teaching. Unpublished MS thesis, School of Information and Library Science, University of North Carolina, Chapel Hill, NC.

Cialdini, R. B., Reno, R. R., \& Kallgren, C. A. (1990). A focus theory of normative conduct: Recycling the concept of norms to reduce littering in public places. Journal of Personality and Social Psychology, 58(6), 1015-1026. doi: 10.1037/00223514.58.6.1015

Charlier, S. D., Giumetti, G. W., Reeves, C. J., \& Greco, L. M. (2017). Workplace cyberdeviance. In G. Hertel, D. L. Stone, R. D. Johnson, \& J. Passmore (Eds.), Wiley Blackwell handbooks in organizational psychology. The Wiley Blackwell handbook of the psychology of the Internet at work (p. 131-156). Wiley-Blackwell. doi: 10.1002/9781119256151.ch7

De Lara, P. Z. M., Tacoronte, D. V., \& Ding, J. M. T. (2006). Do current anti-cyberloafing disciplinary practices have a replica in research findings? Internet Research, 16(4), 450-467. doi: 10.1108/10662240610690052

Dursun, O. O., Dönmez, O., \& Akbulut, Y. (2018). Predictors of Cyberloafing among Preservice Information Technology Teachers. Contemporary Educational Technology, 9(1), 22-41.

Fishbein, M., \& Ajzen, I. (1975). Belief, Attitude, Intention, and Behavior: An Introduction to Theory and Research. Reading, MA: Addison-Wesley.

Fishbein, M., \& Ajzen, I. (2011). Predicting and changing behavior: The reasoned action approach. New York: Taylor \& Francis.

Frazier, P. A., Tix, A. P., \& Barron, K. E. (2004). Testing Moderator and Mediator Effects in Counseling Psychology Research. Journal of Counseling Psychology, 51(1), 115-134. Doi: 10.1037/0022-0167.51.1.115

Galluch, P., \& Thatcher, J. (2011). Maladaptive vs. faithful use of internet applications in the Classroom: An empirical examination. Journal of Information Technology Theory and Application (JITTA), 12(1), 5-21.

Gerow, J. E., Galluch, P. S., \& Thatcher, J. B. (2010). To slack or not to slack: internet usage in the classroom. Journal of Information Technology Theory and Application, 11(3), $5-24$. 
Gökçearslan, S., Uluyol, C., \& Şahin, S. (2018). Smartphone addiction, cyberloafing, stress and social support among university students: A path analysis. Children and Youth Services Review, 91, 47-54. doi: 10.1016/j.childyouth.2018.05.036

Greengard, S. (2000). The high cost of cyberslacking employees waste time Online. Workforce, 79(12), 22-24.

Haidari, E. (2018). Investigating the Effect of Cyberloafing on the Sense of Happiness and Academic Engagement of Medical Students. Iranian Journal of Health Education and Health Promotion, 6(3), 203-212.

Hayes, A. F. (2017). Introduction to mediation, moderation, and conditional process analysis, second edition: a regression-based approach. Guilford Publications.

Hayes, A. F., Montoya, A. K., \& Rockwood, N. J. (2017). The analysis of mechanisms and their contingencies: PROCESS versus structural equation modeling. Australasian Marketing Journal, 25, 76-81.

Kalayc1, E. (2010). Üniversite öğrencilerinin siber aylaklık davranışları ile özdüzenleme stratejileri arasindaki ilişkinin incelenmesi [The investigation of relationship between cyberloafing and self-regulated learning strategies among undergraduate students] (unpublished doctoral dissertation). Hacettepe University, Ankara, Turkey.

Kırmızı, Ö. (2014). Measuring technology acceptance level of Turkish pre-service English teachers by using technology acceptance model. Educational Research and Reviews, 9(23), 1323-1333.

Koay, K. Y. (2018). Assessing cyberloafing behaviour among university students: A validation of the cyberloafing scale. Pertanika Journal Social Sciences \& Humanities, 26(1), 409-424.

Lapinski, M. K., \& Rimal, R. N. (2005). An explication of social norms. Communication Theory, $15,127-147$.

Lim, V. K. (2002). The IT way of loafing on the job: Cyberloafing, neutralizing and organizational justice. Journal of organizational behavior, 23(5), 675-694.

Lim, V. K., \& Chen, D. J. (2012). Cyberloafing at the workplace: gain or drain on work? Behaviour \& Information Technology, 31(4), 343-353.

Mantovani, D., \& Martini, E. (2008). Children of immigrants in Trento: Educational achievement through the lens of friendship. Intercultural Education, 19, 435-447.

Park, H. S., \& Smith, S. W. (2007). Distinctiveness and Influence of Subjective Norms, Personal Descriptive and Injunctive Norms, and Societal Descriptive and Injunctive Norms on Behavioral Intent: A Case of Two Behaviors Critical to Organ Donation. Human Communication Research, 33(2), 194-218. doi: 10.1111/j.14682958.2007.00296.x

Pathirana, P. A., \& Azam, S. M. F. (2017, September). Factors influencing the use of mobile payments - A conceptual model. In 2017 National Information Technology Conference (NITC), Colombo, Sri Lanka (pp. 67-74). Institute of Electrical and Electronics Engineers (IEEE).

Pim, C. (2013). Emerging technologies, emerging minds: digital innovations within the primary sector. In G. Motteram (ed). Innovations in Learning Technologies for English Language Teaching (pp. 15-42). London, UK: The British Council.

Polito, A. (1997). Cyberloafing can be curbed. Workforce, 76(3), 18.

Preacher, K. J., \& Hayes, A. F. (2004). SPSS and SAS procedures for estimating indirect effects in simple mediation models. Behavior Research Methods, Instruments, \& Computers, 36, 717-731. https://doi.org/10.3758/BF03206553

Preacher, K. J., \& Hayes, A. F. (2008). Asymptotic and resampling strategies for assessing and comparing indirect effects in multiple mediator models. Behavior Research Methods, 40(3), 879-891. doi: 10.3758/brm.40.3.879 
Ravizza, S. M., Hambrick, D. Z., \& Fenn, K. M. (2014). Non-academic internet use in the classroom is negatively related to classroom learning regardless of intellectual ability. Computers \& Education, 78, 109-114. doi: 10.1016/j.compedu.2014.05.007

Rodríguez-Gómez, D., Castro, D., \& Meneses, J. (2018). Problematic uses of ICTs among young people in their personal and school life. Comunicar, 26(56), 91-100. doi: 10.3916/c56-2018-09

Saritepeci, M. (2019). Predictors of cyberloafing among high school students: unauthorized access to school network, metacognitive awareness, and smartphone addiction. Education and Information Technologies, 25, 2201-2219.

Sarstedt, M., Hair, J. F., Nitzl, C., Ringle, C. M., \& Howard, M. C. (2020). Beyond a tandem analysis of SEM and PROCESS: Use of PLS-SEM for mediation analyses! International Journal of Market Research, 62(3), 288-299. doi:10.1177/1470785320915686

Schepers, J., \& Wetzels, M. (2007). A meta-analysis of the technology acceptance model: Investigating subjective norm and moderation effects. Information \& Management, 44(1), 90-103.

Seçkin, Z., \& Kerse, G. (2017). Üniversite öğrencilerinin sanal kaytarma davranışları ve bu davranışların çesitli değişkenler açısından incelenmesi: ampirik bir araştırma [Cyberloafing behaviors of university students and an examination of such behaviors in view of assorted variables: an empirical research]. Journal of Aksaray University Faculty of Economics and Administrative Sciences, 9(1), 89-110.

Scherer, R., Siddiq, F., \& Tondeur, J. (2019). The technology acceptance model (TAM): A meta-analytic structural equation modeling approach to explaining teachers' adoption of digital technology in education. Computers \& Education, 128, 13-35.

Skolnik, R., \& Puzo, M. (2008). Utilization of laptop computers in the school of business classroom. Academy of Educational Leadership Journal, 12(2), 1-10.

Sobel, M. E. (1982). Asymptotic confidence intervals for indirect effects in structural equation models. In S. Leinhart (Ed.), Sociological methodolog (pp. 290-312). San Francisco: Jossey-Bass

Soh, P. C. H., Koay, K. Y., \& Lim, V. K. (2018). Understanding cyberloafing by students through the lens of an extended theory of planned behavior. First Monday, 23(6). Doi: $10.5210 / \mathrm{fm} . \mathrm{v} 23 \mathrm{i} 6.7837$.

Stewart, F. (2000). Internet acceptable use policies: Navigating the management, legal, and technical issues. Information Systems Security, 9(3), 1-7.

Szajna, B. (1996). Empirical evaluation of the revised technology acceptance model. Management Science, 42, 85-92

Taneja, A., Fiore, V., \& Fischer, B. (2015). Cyberslacking in the classroom: potential for digital distraction in the new age. Computers \& Education, 82, 141-151.

Tao, D. (2008). Using theory of reasoned action (TRA) in understanding selection and use of information resources: an information resource selection and use model (unpublished doctoral dissertation), University of Missouri, Columbia, US.

Teo, T. (2009). Modelling technology acceptance in education: A study of pre-service teachers. Computers \& Education, 52(1), 302-312.

Teo, T., Lee, C. B., Chai, C. S., \& Wong, S. L. (2009). Assessing the intention to use technology among pre-service teachers in Singapore and Malaysia: A multigroup invariance analysis of the technology acceptance model (TAM). Computers \& Education, 53(3), 1000-1009.

Teo, T., \& Milutinovic, V. (2015). Modelling the intention to use technology for teaching mathematics among pre-service teachers in Serbia. Australasian Journal of Educational Technology, 31(4), 363-380. doi: 10.14742/ajet.1668 
Teo, T., \& van Schaik, P. (2012). Understanding the intention to use technology by preservice teachers: an empirical test of competing theoretical models. International Journal of Human-Computer Interaction, 28(3), 178-188. doi: 10.1080/10447318.2011.581892

Varol, F., \& Yıldırım, E. (2017). Siberaylaklik: öğretmen adayları ve mobil teknolojiler [Cyberloafing: teacher candidates and mobile technologies]. Mersin University Journal of the Faculty of Education, 13(3), 1046-1057. doi: 10.17860/mersinefd.321313.

Varol, F., \& Y1ldırım, E. (2018). An examination of cyberloafing behaviors in classrooms from students' perspectives. Turkish Online Journal of Qualitative Inquiry, 9(1), 2646.

Yasmin, M., Naseem, F., \& Masso, I. C. (2019). Teacher-directed learning to self-directed learning transition barriers in Pakistan. Studies in Educational Evaluation, 61, 34-40.

Yılmaz, F. G. K., Yılmaz, R., Özturk, H. T., Sezer, B., \& Karademir, T. (2015). Cyberloafing as a barrier to the successful integration of information and communication technologies into teaching and learning environments. Computers in Human Behavior, 45, 290-298. 